\title{
Transgenic Passionfruit Expressing RNA Derived from Cowpea aphid-borne mosaic virus Is Resistant to Passionfruit Woodiness Disease
}

\author{
Poliane F. Alfenas ${ }^{1 *}$, Antonio Sérgio K. Braz ${ }^{1 *}$, Leonardo B. Torres ${ }^{1}$, Enilton N. Santana ${ }^{1}$, Ana Verônica \\ S. do Nascimento ${ }^{1}$, Murilo G. de Carvalho ${ }^{1}$, Wagner C. Otoni ${ }^{2}$ \& F. Murilo Zerbini ${ }^{1}$
}

'Departamento de Fitopatologia/BIOAGRO, e-mail: zerbini@ufv.br; ²Departamento de Biologia Vegetal/ BIOAGRO, Universidade Federal de Viçosa, CEP 36570-000, Viçosa, MG, Brazil

(Accepted for publication 16/09/2004)

Corresponding author: Murilo Zerbini

ALFENAS, P.F., BRAZ, A.S.K., TORRES, L.B., SANTANA, E.N., NASCIMENTO, A.V.S., CARVALHO, M., OTONI, W.C. \& ZERBINI, F.M. Transgenic passionfruit expressing RNA derived from Cowpea aphid-borne mosaic virus is resistant to passionfruit woodiness disease. Fitopatologia Brasileira 30:33-38. 2005.

\begin{abstract}
Sixteen transgenic yellow passionfruit (Passiflora spp.) plants $\left(\mathrm{R}_{0}\right)$ were obtained which express a non-translatable transgenic RNA corresponding to the 3' region of the $N I b$ gene and the 5' region of the $C P$ gene, derived from the genome of a Brazilian isolate of Cowpea aphid-borne mosaic virus (CABMV). The transgenic plants were propagated by stem cuttings and challenged by sap inoculation with isolates CABMV-MG1 and CABMV-PE1. One transgenic plant (TE5-10) was resistant to the isolate CABMV-MG1, but susceptible to CABMV-PE1. The remaining transgenic plants developed systemic symptoms, equal to non-transformed plants, when inoculated with either isolate. The absence of virus in TE5-10 plants was confirmed by indirect ELISA. Transcription analysis of the transgene demonstrated that the TE5-10 plant did not accumulate transgenic mRNA, even before inoculation. After inoculation, viral RNA was only detected in plants inoculated with CABMV-PE1. These results confirm that the transgenic plant TE5-10 is resistant to isolate CABMV-MG1, and suggest that the resistance mechanism is post-transcriptional gene silencing, which is already activated in the transgenic plants before virus inoculation.
\end{abstract}

Additional keywords: Passionfruit woodiness virus, PWV, potyvirus, resistance.

\section{RESUMO}

Plantas transgênicas de maracujá-amarelo expressando um RNA derivado do genoma do Cowpea aphid-borne mosaic virus são resistentes ao endurecimento dos frutos

Dezesseis plantas transgênicas $\left(\mathrm{R}_{0}\right)$ de maracujá-amarelo (Passiflora spp.) foram obtidas expressando um RNA nãotraduzível correspondente à região 3' do gene $N I b$ e 5' do gene $C P$ de um isolado brasileiro do CABMV. As plantas $\mathrm{R}_{0}$ foram propagadas vegetativamente por estaquia e inoculadas com os isolados CABMV-MG1 e CABMV-PE1. Uma das plantas (TE5-10) foi resistente ao isolado CABMV-MG1, porém suscetível ao isolado CABMV-PE1. As demais plantas transgênicas foram suscetíveis a ambos os isolados, apresentando sintomas sistêmicos semelhantes ao de plantas não-transformadas. A ausência de replicação viral nas plantas TE5-10 foi confirmada por ELISA indireto. A análise da transcrição do transgene nas plantas TE5-10 demonstrou que estas não acumulam o mRNA transgênico, mesmo antes da inoculação com o vírus. Após a inoculação, o RNA viral foi detectado apenas em plantas inoculadas com o isolado CABMV-PE1. Esses resultados confirmam que a planta TE5-10 é resistente ao isolado CABMV-MG1, e sugerem que o mecanismo da resistência é baseado em silenciamento gênico pós-transcricional, o qual já se encontra ativado nas plantas antes da inoculação com o vírus.

Palavras-chave adicionais: Passionfruit woodiness virus, PWV, potyvirus, resistência, maracujá amarelo.

\section{INTRODUCTION}

Passionfruit woodiness is one of the most important diseases of the passionfruit (Passiflora spp.) (Kitajima \& Chagas, 1984; Chagas, 1991). The causative agent was described and named Passionfruit woodiness virus (PWV) by Cobb, in Australia, in 1901 (cited by Shukla et al., 1988). Shukla et al. (1988) determined the amino acid sequence of the capsid

\footnotetext{
*These authors have contributed equally to this work.
}

protein (CP) of three PWV isolates of Australasian origin. Later, McKern et al. (1994) showed that an isolate from South Africa classified as PWV was actually a member of a distinct species, designated South African passiflora virus (SAPV). Additional studies identified SAPV as a strain of Cowpea aphid-borne mosaic virus (CABMV) (Sithole Niang et al., 1996). Therefore, it is currently acknowledged that passionfruit woodiness disease can be caused by PWV or CABMV, family Potyviridae, genus Potyvirus (Van Regenmortel et al., 2000). Phylogenetic analysis based on the capsid 
protein amino acid sequence grouped a number of Brazilian isolates causing passionfruit woodiness disease together with CABMV, distant from PWV isolates, indicating that they comprise a strain of CABMV (Nascimento et al., 2004).

The control of passionfruit woodiness disease is difficult and often impossible, mostly due to the noncirculative mode of virus transmission by aphid vectors and to the fact that both CABMV and PWV have several wild hosts that can serve as virus reservoirs (Taylor \& Greber, 1973; Bock \& Conti, 1974). Cross-protection would be an alternative control method. However, reports of a synergistic effect between PWV and Cucumber mosaic virus (CMV), family Bromoviridae, genus Cucumovirus, causing tip necrosis (Pares et al., 1985) have hindered the use of cross-protection. Breeding for resistance is complicated by self-incompatibility and inter-specific incompatibility in Passiflora species (Martin \& Nakasone, 1970; Lopes, 1994; Bruckner et al., 2002). An interesting alternative control method would be the use of transgenic plants with pathogen-derived resistance (PDR).

Transgenic plants expressing genes or partial viral sequences can be resistant to viral infection (Goldbach et al., 2003). This form of resistance is known as PDR (Sanford \& Johnston, 1985). The PDR can be manifested at the protein or RNA level. Resistance due to protein expression is, in most cases, directly correlated with protein accumulation. On the other hand, RNA-mediated resistance is typically associated with transgenic plants which accumulate the transgenic mRNA at low or non-detectable levels. This kind of resistance is known as homology-dependent resistance (Baulcombe, 1996) and is associated with the process of post-transcriptional gene silencing (PTGS) (Baulcombe, 2002; Goldbach et al., 2003), which leads to the highly sequence-specific degradation of a homologous RNA population (Baulcombe, 2002). This phenomenon was first observed in transgenic plants when the introduction of a second copy of an endogenous gene led to the inactivation (silencing) of the transgene itself and the homologous endogene (Napoli et al., 1990; Smith et al., 1990; Van Der Krol et al., 1990).

In this study, we showed that transgenic yellow passionfruit (Passiflora edulis f. flavicarpa) plants expressing an untranslatable RNA encompassing the 3'terminal region of the $N I b$ gene and the 5'-terminal region of the $C P$ gene from isolate CABMV-MG1 are resistant to the virus. Transcription analysis of the transgene indicates that the resistance mechanism is PTGS, which is already active even in the absence of viral replication.

\section{MATERIALSAND METHODS}

\section{Viral isolates}

The viral isolates used in this study were obtained by Costa (1996) in the states of Pernambuco (isolate PE1) and Minas Gerais (isolate MG1). The isolates were stored at -20 ${ }^{\circ} \mathrm{C}$, in the form of dried leaf material of common bean (Phaseolus vulgaris L.) cv. Preto 153. After reactivation by sap-inoculation onto 'Preto 153' bean and yellow passionfruit plants, the isolates were maintained in plants of these species under greenhouse conditions. Inoculations were carried out mechanically using potassium phosphate buffer $0.05 \mathrm{M}, \mathrm{pH} 7.2$, with $0.1 \%$ (p/v) sodium sulfite, and carborundum as an abrasive.

\section{Cloning of $N I b$ and $C P$ genes}

Concentrated viral preparations of isolate CABMVMG1 were obtained from infected leaves of 'Preto 153' bean according to Lane (1992). Viral RNA was extracted as described by Krause-Sakate et al. (2001). An oligo-dT (5'-G-A-C-T-G-GA-T-C-C-T $14^{-3}$, BamH I site underlined), which is supposed to anneal at the poly-A sequence at the 3'-end of the viral genome, was used for cDNA synthesis. The same primer was used for amplification of the $N I b$ and $C P$ genes, together with a degenerate primer which anneals at the $N I b$ gene (5'-G-C-GG-G-A-T-C-C-G-T-N-T-G-Y-G-T-N-G-A-Y-G-A-Y-T-T-T-Y-A-AY-A-A-3', BamH I site underlined), as described (Braz, 1999). After digestion with $B a m \mathrm{H} \mathrm{I}$, amplified fragments were ligated to the pBluescript KS+ vector, previously digested with the same enzyme. The fragment was subcloned into the expression cassette of the binary vector pBI121 and transferred to the Agrobacterium tumefaciens strain LBA 4404.

\section{Plant transformation}

Transformation of leaf disks of yellow passionfruit was mediated by A. tumefaciens. The explants were immersed in a suspension of $A$. tumefaciens $\left(\mathrm{OD}_{600} 0.4\right)$ for 15 to $20 \mathrm{~min}$, transferred to non-selective MS medium ( $3 \%$ sucrose, $0.1 \mathrm{mg}$ / $1 \mathrm{BAP}, 100 \mathrm{mg} / \mathrm{l}$ vitamin B5 complex, $50 \mathrm{mg} / \mathrm{l}$ myo-inositol, $0.26 \%$ phytagel, $\mathrm{pH} 5.8$ ) and kept in darkness for $48 \mathrm{~h}$. Transgenic plants were regenerated in selective medium containing kanamicin $(150 \mathrm{mg} / \mathrm{l})$ and cefotaxim $(500 \mathrm{mg} / \mathrm{l})$. After stem elongation, these were transferred to rooting medium (1/ $2 \mathrm{MS}, 2 \%$ sucrose, $100 \mathrm{mg} / \mathrm{l}$ vitamin B5 complex, $50 \mathrm{mg} / \mathrm{l} \mathrm{myo-}$ inositol, $500 \mathrm{mg} / 1$ cefotaxim, $0.88 \mathrm{mg} / 1 \mathrm{IAA}, 0.26 \%$ phytagel, $\mathrm{pH}$ 5.8). Rooted plants were transferred to substrate and, after acclimation, maintained in a greenhouse. The presence of the T-DNA was determined by polymerase chain reaction (PCR) based on genomic DNA extracted from the regenerated plants as described by Gama (1998) using specific primers for the $n p t I I$ gene (5'-C-C-G-G-T-C-A-G-C-C-C-A-T-T-C-G-C-C-G-CC-3' and 5'-T-C-A-G-C-G-C-A-G-G-G-G-C-G-C-C-C-G-G-T-T-3') which allow the amplification of a DNA fragment of $800 \mathrm{nt}$.

\section{Resistance to CABMV in $R_{0}$ plants}

The transgenic plants were vegetatively propagated by removing cuttings of approximately $20 \mathrm{~cm}$ from the $\mathrm{R}_{0}$ plants. About four centimeters of the base of each cutting was immersed for $5 \mathrm{~min}$ in $200 \mathrm{mg} / \mathrm{l} \mathrm{IBA}$, and transferred to plastic trays containing sterile sand (the treated end into the sand bed), and kept for the next 20 days under greenhouse conditions. The cuttings were then transferred to pots and maintained in the greenhouse until they developed four-six leaves. At this point, cuttings were sap-inoculated as described 
Transgenic passionfruit expressing an RNA derived from...

above. Five plants per transformant were inoculated with CABMV isolate MG1, five with isolate PE1, and three were mock-inoculated with buffer. After three days, all plants were reinoculated to avoid escapes. Plants were maintained under greenhouse conditions and visually evaluated for the incidence of symptoms until 45 days after inoculation. The experiment was repeated four times, for a total of 20 inoculated plants derived from each $\mathrm{R}_{0}$ transformant. Virus identification in inoculated plants was carried out by indirect ELISA using a polyclonal antiserum raised against isolate MG1 (Costa, 1996).

\section{Analysis of transgene transcription}

Total RNA was extracted from transgenic and nontransgenic plants as described by Mallory et al. (2001). Twenty micrograms of total RNA were separated on a denaturing agarose gel $(1.2 \%)$ and capillary-transferred to a nylon membrane (Hybond-N+, Amersham Biosciences). The clone with the viral fragment in pBluescript $\mathrm{KS}+$ was used as a probe. Approximately $50 \mathrm{ng}$ of DNA were labeled with $\left[\alpha^{32} \mathrm{P}\right]$-dCTP by random priming and hybridization was carried out at high stringency, according to standard techniques (Sambrook et al., 1989).

\section{RESULTS}

\section{Transformation of yellow passionfruit}

Yellow passionfruit plants were transformed with the 3 '-terminal region of the $N I b$ gene and the 5'-terminal region of the $C P$ gene from isolate CABMV-MG1. To determine which $\mathrm{R}_{0}$ plants contained at least one copy of the transgene, we carried out PCR reactions using total DNA from these plants with primers which anneal specifically to the $n p t I I$ gene. The primer pair allows the amplification of a fragment with approximately $800 \mathrm{nt}$ when DNA from the pBI 121 vector, which contains the $n p t I I$ gene, is used as a template (Figure 1, lane 1). Amplification of a fragment of the same size was observed for 15 out of $16 R_{0}$ plants (Figure 1, lanes 3 to 18). No amplification was observed when the total DNA of nontransformed plants was used as a template (Figure 1, lane 2), thus confirming the specificity of the primers. Amplification was not observed with the TE5-2 plant (Figure 1, lane 4), which suggests that this plant was not transformed, or that the TDNA insertion was not complete.

\section{Resistance to CABMV in $\mathbf{R}_{0}$ plants}

In order to determine whether the transgenic lines were resistant to infection by CABMV, the $\mathrm{R}_{0}$ plants were vegetatively propagated by cuttings, and plants developed from the cuttings were sap-inoculated with CABMV isolates MG1 and PE1. Non-transformed plants developed evident mosaic and leaf deformation symptoms upon inoculation with both isolates (Figure 2A, B). Plants obtained from the $\mathrm{R}_{0}$ transformant TE5-10 developed the same symptoms upon inoculation with isolate PE1 (Figure 2C), but did not show any symptoms upon inoculation with isolate MG1 (Figure 2D). This result indicates that the $R_{0}$ plant TE5-10 is resistant to this isolate, the same used for transformation. Plants obtained from the remaining $\mathrm{R}_{0}$ transformants developed mosaic and leaf deformation symptoms upon inoculation with both isolates (data not shown). Results of indirect Enzime Linked Immunosorbent Assay (ELISA), done in all 20 plants propagated from transformant TE5-10 and in 20 nontransformed control plants, were in agreement with the visual observations. Non-transformed plants inoculated with isolates MG1 and PE1 had absorbance values clearly above the positive/negative threshold (twice the absorbance of healthy plants) (Figure 3 ). Plants obtained from the $\mathrm{R}_{0}$ transformant TE5-10 and inoculated with isolate MG1 had absorbance values below the threshold, at the same level as the control plants (Figure 3), demonstrating that these plants were actually virus-free. Plants obtained from the same $R_{0}$ transformant but inoculated with isolate PE1 had absorbance values above the threshold value (Figure 3).

\section{Accumulation of transgenic and viral RNA in $R_{0}$ plants}

Northern blot analysis was carried out to determine whether the plants obtained from the TE5-10 transformant displayed the resistance phenotype due to PTGS.

The transgenic mRNA was detected in a noninoculated plant derived from the susceptible $\mathrm{R}_{0}$ transformant TE5-4 (Figure 4, lane 1), but was not detected in non-inoculated plants derived from the resistant $\mathrm{R}_{0}$ transformant TE5-10 (Figure 4, lane 2). This result indicates that the PTGS mechanism was already activated in TE5-10-derived plants before inoculation with the viral isolates. The fact that transgenic mRNA was not detected in non-transformed plants (Figure 4, lane 3) confirmed the specificity of the probe.

Accumulation of viral RNA was detected in TE5-10derived plants after inoculation with CABMV-PE1 (Figure 4, lane 7), evidence of viral replication in these plants. However, it was not detected in TE5-10-derived plants after inoculation with CABMV-MG1 (Figure 4, lane 6), further evidence that viral replication did not take place in these plants. Viral RNA accumulation was also detected in non-transformed plants inoculated with both isolates (Figure 4, lanes 4 and 5), which confirmed that the probe could detect both isolates.

\section{DISCUSSION}

Results obtained in this study demonstrate that the construct used to transform yellow passionfruit was efficient to confer resistance to isolate CABMV-MG1, and suggest that the resistance mechanism is PTGS.

Resistance in the TE5-10 transgenic plant was specific against isolate MG1. Plants derived from this transformant were susceptible to infection by isolate PE1. The resistance against isolate MG1 can be explained based on the mechanism of PTGS (Waterhouse et al., 2001), since the sequence used for transformation is derived from the genome of this isolate. Sequence comparisons between these two isolates indicate an identity of $92 \%$ for the amino acid sequence of the capsid protein and of $94 \%$ for the nucleotide sequence of the 3 'NTR 


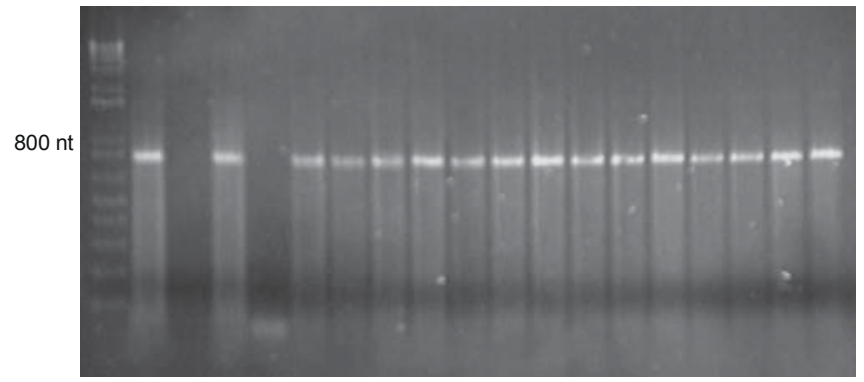

FIG. 1 - Polymerase chain reaction (PCR) - amplification products of the $n p t \mathrm{II}$ gene. Total DNA extracted from transformed yellow passionfruit (Passiflora edulis f. flavicarpa) plants (lanes 3 to 18, corresponding to the $\mathrm{R}_{0}$ plants TE5-1 to TE5-16, respectively), nontransformed plant (lane 2) and plasmid DNA of pBI121 (lane 1). M, size marker ("1 kb Plus DNA ladder"). The size of the amplified fragment is indicated at the left.

(Nascimento et al., submitted). While this level of identity is sufficient to classify these isolates as members of the same viral species (Van Regenmortel et al., 2000), there could be enough nucleotide differences between MG1 and PE1 to prevent recognition of the PE1 RNA by the silencing machinery activated in the TE5-10 plants. Also, CABMV-PE1 could present differences in HC-Pro, which may determine that the HC-Pro of this isolate is a more efficient silencing suppressor than the HC-Pro of isolate MG1.

It has been demonstrated that in papaya plants transformed with the capsid protein gene of Papaya ringspot virus (PRSV), family Potyviridae, genus Potyvirus, resistance against a wide range of isolates is dependent on gene dosage, that is, plants that are homozygous for the transgene are resistant to several isolates of the virus (Lius et al., 1997; Tennant et al., 2001). Since the $\mathrm{R}_{0}$ plants that we tested are hemizygous, it is possible that $\mathrm{R}_{1}$ plants will be resistant to other isolates when in homozygosis for the transgene.

The fact that $A$. tumefaciens-mediated genetic transformation is a random process may explain why only one $\mathrm{R}_{0}$ plant was resistant. Inverted repeat copies might have been inserted into the TE5-10 plant, which would facilitate the production of double stranded RNA required to trigger the silencing mechanism. Still, Southern blot and PCR analyses are required to determine the copy number and orientation of transgene insertions into these plants. Another factor that must be taken into consideration is the occurrence of methylation in the coding region of the transgene, since it has been proposed that methylation may lead to the production
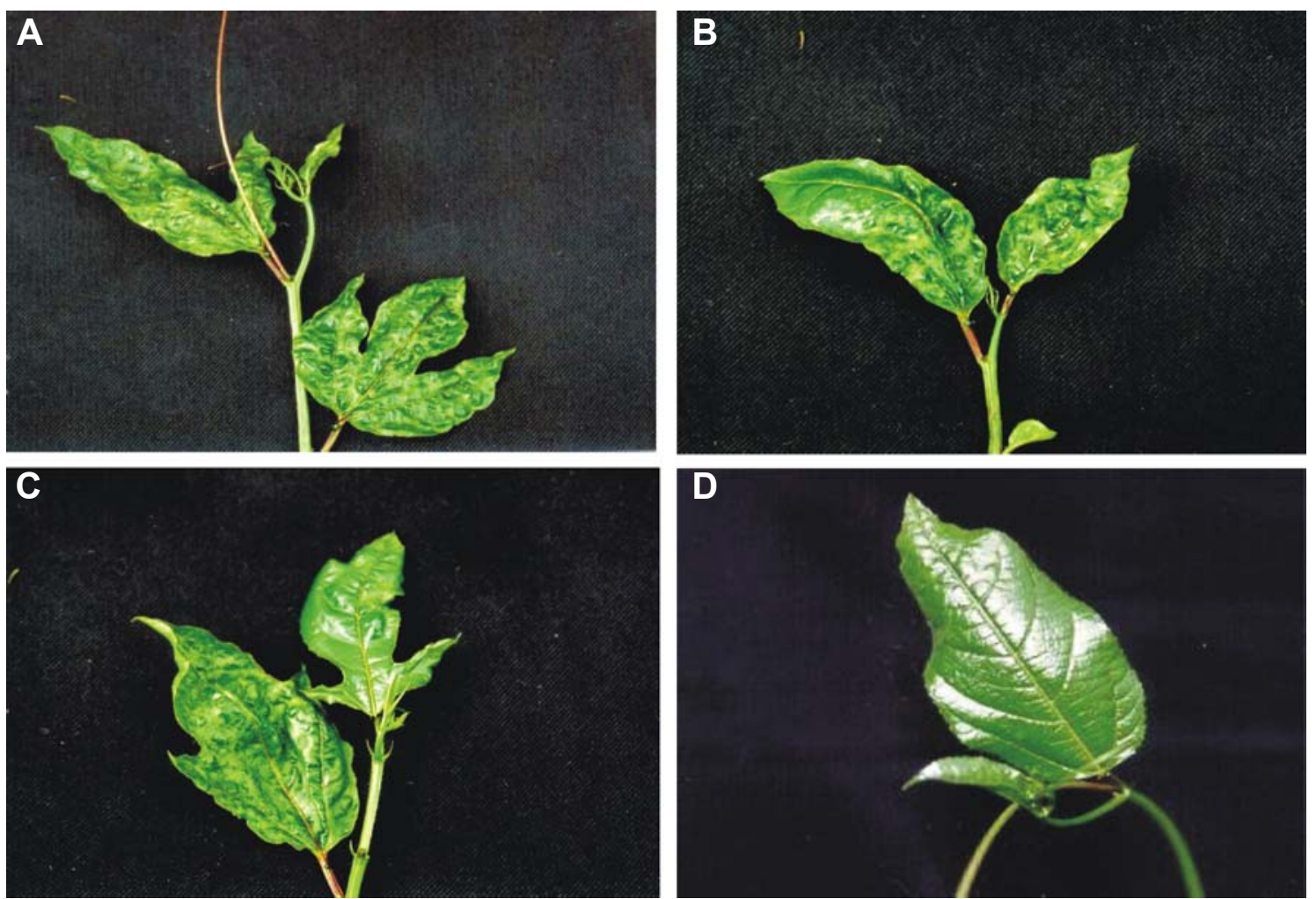

FIG. 2 - Symptoms observed in inoculated yellow passionfruit (Passiflora edulis f. flavicarpa) plants. A, B - Nontransformed plant inoculated with isolates Cowpea aphid-borne mosaic virus (CABMV) -PE1 and -MG1, respectively, showing mosaic and leaf deformation symptoms at 14 days post-inoculation (dpi). C - Transformed plant derived from the TE5-10 plant and inoculated with isolate CABMV-PE1, showing the same symptoms as the non-transformed control, at 14 dpi. D - TE5-10-derived plant inoculated with CABMV-MG1, showing no symptoms at 35 dpi. 
Transgenic passionfruit expressing an RNA derived from...

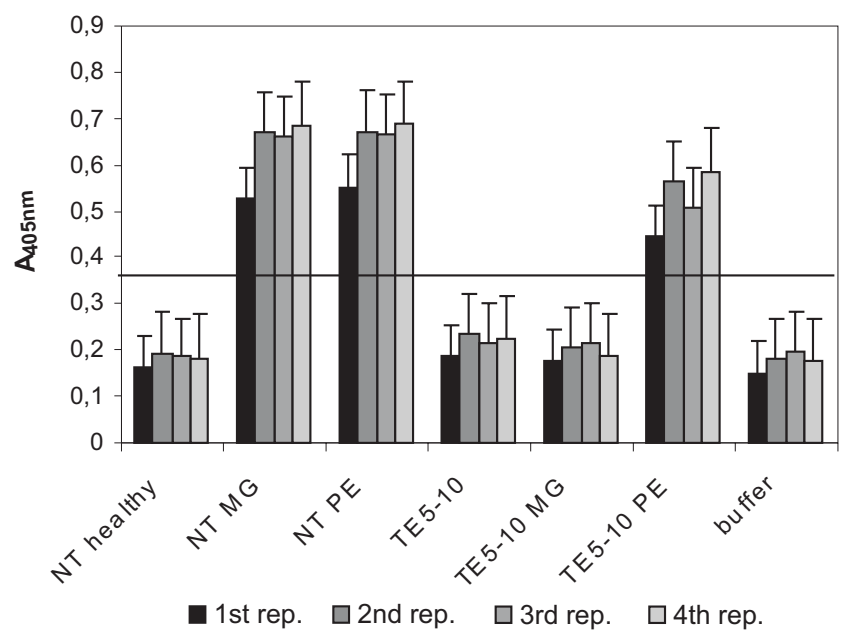

FIG. 3 - Virus detection via indirect ELISA in transgenic yellow passionfruit (Passiflora edulis f. flavicarpa) plants inoculated with isolates Cowpea aphid-borne mosaic virus (CABMV) -MG1 and PE1; NT healthy, Non-transformed, non-inoculated plant. NT MG, Non-transformed plants inoculated with CABMV-MG1; NT PE, Non-transformed plants inoculated with CABMV-PE1; TE5-10, Noninoculated plants derived from the TE5-10 transformant; TE5-10 MG, TE5-10-derived plants inoculated with CABMV-MG1; TE510 PE, TE5-10-derived plants inoculated with CABMV-PE1. Buffer, grinding buffer for I-ELISA. Each vertical bar represents the average absorbance value of five plants, for a total of 20 plants tested for each treatment. The horizontal line represents the positive/negative threshold, which corresponds to twice the absorbance value for healthy, non-inoculated plants.

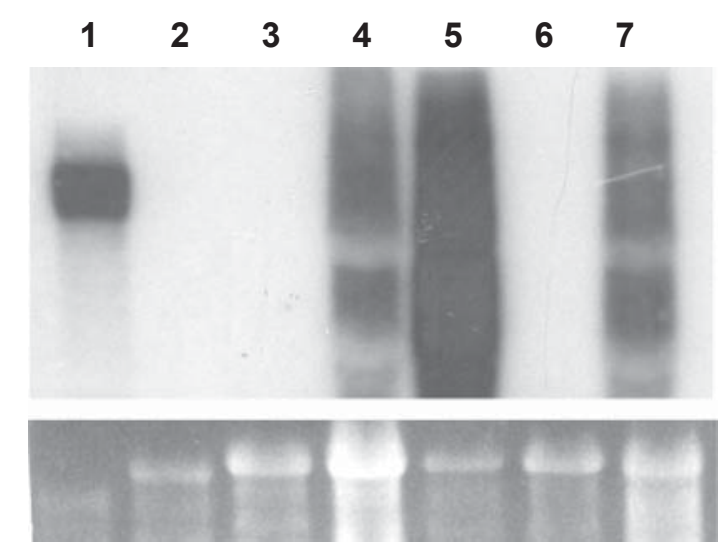

FIG. 4 - Expression analysis of the transgene in $\mathrm{R}_{0}$ yellow passionfruit (Passiflora edulis f. flavicarpa) plants resistant or susceptible to Cowpea aphid-borne mosaic virus (CABMV). Total RNA was extracted from inoculated or non-inoculated plants derived from the $\mathrm{R}_{0}$ plants TE5-4 (susceptible) and TE5-10 (resistant) and hybridized with a specific probe for the $N I b$ and $C P$ genes of CABMV. 1, TE54-derived plant, non-inoculated. 2, TE5-10-derived plant, noninoculated. 3, Non-transformed, non-inoculated plant. 4, 5, Nontransformed plants inoculated with CABMV-MG1 and CABMVPE1, respectively. 6, 7, TE5-10-derived plants inoculated with CABMV-MG1 and CABMV-PE1, respectively. Ethidium bromidestained gel prior to transfer in the region corresponding to the $25 \mathrm{~S}$ rRNA is shown at the bottom. of aberrant mRNAs, which in turn could trigger the PTGS mechanism (Wassenegger, 2000).

Our results demonstrate that CABMV-resistant transgenic passionfruit plants have the potential to provide adequate control of passionfruit woodiness disease. The $\mathrm{R}_{0}$ plants are currently being self-crossed in order to generate homozygous $\mathrm{R}_{1}$ lines. If these $\mathrm{R}_{1}$ lines display a broader spectrum of resistance, field trials would be the next logical step towards the commercial application of transgenic passionfruit.

\section{ACKNOWLEDGMENTS}

The authors wish to thank Dr. Antonio Félix da Costa (IPA, Recife, PE) for the collection of viral isolates and support for this work, and Dra. Elza Fernandes de Araújo (UFV, Viçosa, $\mathrm{MG}$ ) for assistance with the Northern blot analysis. This work was supported by FAPEMIG grants CAG1139/97 and CAG813/ 99, and CNPq grant 479625/2001-8 to FMZ.

\section{LITERATURE CITED}

BAULCOMBE, D. RNA silencing. Current Biology 12:82-84. 2002. BAULCOMBE, D.C. Mechanisms of pathogen-derived resistance to viruses in transgenic plants. Plant Cell 8:1833-1844. 1996.

BOCK, K.R. \& CONTI, M. Cowpea aphid-borne mosaic virus. CMI/AAB Descriptions of Plant Viruses 134. 1974.

BRAZ, A.S.K. Clonagem e sequenciamento dos genes da proteína capsidial e da replicase de um Potyvirus causador de endurecimento dos frutos do maracujazeiro, e transformação de maracujá-amarelo com construção derivada desses genes. Tese M.S., Dep. de Fitopatologia, Universidade Federal de Viçosa, Viçosa, MG. 1999.

BRUCKNER, C.H., MELlETTI, L.M.M., OTONI, W.C. \& ZERBINI, F.M. Maracujazeiro. In: Bruckner, C.H. (Ed.) Melhoramento de fruteiras tropicais. Viçosa, MG: Editora UFV. 2002. pp.373-409

CHAGAS, C.M. Doenças viróticas e similares do maracujazeiro no Brasil. In: São José, A.R., Ferreira, F.R. \& Vaz, R.L. (Eds.) A cultura de maracujá no Brasil. Jaboticabal: FUNEP. 1991. pp.175-186.

COSTA, A.F. Comportamento de Passiflora spp. diante do vírus do endurecimento dos frutos do maracujazeiro e a relação entre a nutrição mineral e a interação vírus-Passiflora edulis f. flavicarpa. Tese de Doutorado, Dep. de Fitopatologia, Universidade Federal de Viçosa, Viçosa. 1996.

GAMA, M.I.C.S. Identificação de plantas transgênicas por PCR. In: Brasileiro, A.C.M. \& Carneiro, V.T.D.C. (Eds.) Manual de Transformação Genética de Plantas. Brasília: Embrapa. 1998. pp.179-189

GOLDBACH, R., BUCHER, E. \& PRINS, M. Resistance mechanisms to plant viruses: An overview. Virus Research 92:207212. 2003.

KITAJIMA, E.W. \& CHAGAS, C.M. Problemas de viroses ou de etiologia micoplasmática na cultura do maracujazeiro no Brasil. Fitopatologia Brasileira 9:393. 1984. (Abstract)

KRAUSE-SAKATE, R., MELLO, R.N., ZAMBOLIM, E.M., PAVAN, M.A., CARVALHO, M.G., LE GALL, O. \& ZERBINI, F.M. Molecular characterization of two Brazilian isolates of Lettuce 
mosaic virus (LMV) with distinct biological properties. Fitopatologia Brasileira 26:153-157. 2001.

LANE, L.C. A general method for detecting plant viruses. In: Maramorosch, K. (Ed.) Plant diseases of viral, viroid, mycoplasma and uncertain origin. New Delhi: Oxford \& IBH Publishing. 1992. pp.3-17.

LIUS, S., MANSHARDT, R.M., FITCH, M.M.M., SLIGHTOM, J.L., SANFORD, J.C. \& GONSALVES, D. Pathogen-derived resistance provides papaya with effective protection against Papaya ringspot virus. Molecular Breeding 3:161-168. 1997.

LOPES, S.C. Citogenética do maracujazeiro - Passiflora spp. In: São José, A.R. (Ed.) Maracujá, produção e mercado. Vitória da Conquista: UESB. 1994. pp.19-23.

MALLORY, A.C., ELY, L., SMITH, T.H., MARATHE, R., ANANDALAKSHMI, R., FAGARD, M., VAUCHERET, H., PRUSS, G., BOWMAN, L. \& VANCE, V.B. HC-Pro suppression of transgene silencing eliminates the small RNAs but not transgene methylation or the mobile signal. Plant Cell 13:571-583. 2001.

MARTIN, F.W. \& NAKASONE, H.Y. The edible species of Passiflora. Economical Botany 24:333-343. 1970.

McKERN, N.M., STRIKE, P.M., BARNETT, O.W., DIJKSTRA, J., SHUKLA, D.D. \& WARD, C.W. Cowpea aphid borne mosaic virus-Morocco and South African Passiflora virus are strains of the same potyvirus. Archives of Virology 136:207-217. 1994.

NAPOLI, C., LEMIEUX, C. \& JORGENSEN, R. Introduction of a chimeric chalcone synthase gene into petunia results in reversible co-suppression of homologous genes in trans. Plant Cell 2:279-289. 1990.

NASCIMENTO, A.V.S., SOUZA, A.R.R., ALFENAS, P.F., ANDRADE, G.P., CARVALHO, M.G., PIO-RIBEIRO, G. \& ZERBINI, F.M. Análise filogenética de potyvírus causando endurecimento dos frutos do maracujazeiro no Nordeste do Brasil. Fitopatologia Brasileira 29:378-383. 2004.

PARES, R.D., MARTIN, A.B. \& FITZELL, R.D. Virus-induced tip necrosis of passionfruit (Passiflora edulis Sims.). Australian Plant Pathology 14:76-78. 1985.

SAMBROOK, J., FRITSCH, E.F. \& MANIATIS, T. Molecular Cloning - A Laboratory Manual (2 ${ }^{\mathrm{a}}$ ed.). Cold Spring Harbor, NY:
Cold Spring Harbor Laboratory Press. 1989.

SANFORD, J.C. \& JOHNSTON, S.A. The concept of parasitederived resistance - Deriving resistance genes from the parasite's own genome. Journal of Theoretical Biology 113:395-405. 1985.

SHUKLA, D.D., MCKERN, N.M. \& WARD, C.W. Coat protein of potyviruses. 5. Symptomatology, serology and coat protein sequences of three strains of passionfruit woodiness virus. Archives of Virology 102:221-232. 1988.

SITHOLE NIANG, I., NYATHI, T., MAXWELL, D.P. \& CANDRESSE, T. Sequence of the 3'-terminal region of a Zimbabwe isolate of cowpea aphid-borne mosaic virus (CABMV). Archives of Virology 141:935-943. 1996.

SMITH, C.J.S., WATSON, C.F., BIRD, C.R., RAY, J., SCHUCH, W. \& GRIERSON, D. Expression of a truncated tomato polygalacturonase gene inhibits expression of the endogenous gene in transgenic plants. Molecular and General Genetics 224:477-481. 1990.

TAYLOR, R.H. \& GREBER, R.S. Passionfruit woodiness virus. CMI/AAB Descriptions of Plant Viruses 122. 1973.

TENNANT, P., FERMIN, G., FITCH, M.M., MANSHARDT, R.M., SLIGHTOM, J.L. \& GONSALVES, D. Papaya ringspot virus resistance of transgenic Rainbow and SunUp is affected by gene dosage, plant development, and coat protein homology. European Journal of Plant Pathology 107:645-653. 2001.

VAN DER KROL, A.R., MUR, L.A., BELD, M., MOL, J.N.M. \& STUITJE, A.R. Flavonoid genes in petunia: Addition of a limited number of gene copies may lead to a suppression of gene expression. Plant Cell 2:291-299. 1990.

VAN REGENMORTEL, M.H.V., FAUQUET, C.M., BISHOP, D.H.L., CARSTENS, E., ESTES, M.K., LEMON, S.M., MANILOFF, J., MAYO, M.A., MCGEOCH, D.J., PRINGLE, C.R. \& WICKNER, R.B. (Eds.) Virus Taxonomy. Seventh Report of the International Committee on Taxonomy of Viruses. San Diego: Academic Press. 2000.

WASSENEGGER, M. RNA-directed DNA methylation. Plant Molecular Biology 43:203-220. 2000.

WATERHOUSE, P.M., WANG, M.B. \& LOUGH, T. Gene silencing as an adaptive defence against viruses. Nature 411:834-842. 2001. 